\title{
CAT wt Allele
}

National Cancer Institute

\section{Source}

National Cancer Institute. CAT wt Allele. NCI Thesaurus. Code C61061.

Human CAT allele is located at $11 \mathrm{p} 13$ and is approximately $33 \mathrm{~kb}$ in length. This gene, which encodes catalase protein, is involved in the detoxification of hydrogen peroxide. The CAT gene is associated with susceptibility to essential hypertension. A variant allele of this gene is associated with acatalasia, a disease characterized by the absence of catalase activity in red blood cells, which is typically associated with ulcerating oral lesions. 